\title{
FIRST RECORD OF Dolops striata (BRANCHIURA: ARGULIDAE) ON Arapaima gigas FROM A FISH FARM IN STATE OF PARÁ, BRAZIL
}

\author{
Jeffson Nobre PEREIRA', Germán Augusto Murrieta MOREY ${ }^{2}$, José Celso de Oliveira MALTA ${ }^{1}$ \\ 1 Instituto Nacional de Pesquisas da Amazônia (INPA), Av. André Araújo, 2936 - Petrópolis, Manaus, Amazonas, Brazil \\ 69067-375. Programa de Pós-graduação em Biología de Água Doce e Pesca Interior-BADPI \\ 2 Universidade Federal do Paraná. Laboratório de Ecologia Molecular e Parasitologia Evolutiva (LEMPE), Curitiba, Brasil. \\ $\left({ }^{*}\right)$ Corresponding author: germantiss1106@gmail.com
}

\section{ABSTRACT}

Branchiurans are parasites from the buccal cavity, gills, skin, and fins of various fish species. The Neotropical region has one of the highest diversity of branchiurans. On Arapaima gigas, only four species of branchiurans have been reported. The present study improves the knowledge on host and geographical range of Dolops striata. Fish were collected from a fish farm in the State of Pará, Brazil. All A. gigas were parasitized by Dolops striata, which were collected from the fins and body surface. This is the first record of $D$. striata in A. gigas. The high prevalence detected warns the possibility of an increase in the number of $D$. striata infesting $A$. gigas, which may cause some problems for fish-farmers.

KEYWORDS: Arapaimidae, branchiurans, infestation, parasite.

\section{PRIMER REGISTRO DE Dolops striata (Branchiura: Argulidae) en Arapaima gigas DE UNA HACIENDA DE PECES EN EL ESTADO DE PARÁ, BRASIL}

\section{RESUMEN}

Los branchiuros son parásitos de la cavidad bucal, branquias, piel y aletas de varias especies de peces. La región Neotropical tiene una de las mayores diversidades de especies de branchiuros. Para Arapaima gigas son conocidas únicamente cuatro especies de branchiuros. El presente estudio expande el conocimiento sobre un nuevo hospedero y distribución geográfica de Dolops striata. Los peces examinados fueron de una piscicultura em el Estado de Pará, Brasil. Todos los A. gigas estaban parasitados por Dolops striata, los cuales fueron colectados de las aletas y superficie corporal. Esta es la primera ocurrencia de D. straita en A. gigas. La alta prevalencia detectada alerta la posibilidad de un incremente en el número de $D$. striata infestando $A$. gigas, pudiendo causar algunos problemas para los piscicultores.

PALABRAS CLAVE: Arapaimidae, branchiuros, infestación, parásito 


\section{INTRODUCTION}

Crustaceans of the subclass Branchiura are small ectoparasites with 2 to $3 \mathrm{~mm}$ in length, easily visible to the naked eye and widely known as "fish lice or tick". Branchiurans are very interesting crustaceans because they are able to attach on the slippery surface of several freshwater fishes, as well as swim freely to find a different host (Malta and Varella, 1983; Malta, 1984).

All known branchiuran species belong to the single family Argulidae that includes four genera, Argulus Müller, 1785, Dolops Audouin, 1837, Dipteropeltis Calman, 1912 reported in Brazil and Chonopeltis Thiele, 1900 strictly from Africa. They parasitize buccal cavity, gilsl, skin, and base of the fins of various species of wild and farmed fish (Malta and Varella, 1983; Malta, 1984).

The Neotropical region has one of the highest diversity of species of branchiurans. From the thirtyone-valid species reported infesting freshwater fish as hosts in South America, twenty-seven have been recorded in Brazil and are distributed in 157 fish host species (Luque et al., 2013).

The Arapaima gigas (Schinz, 1822) known as "pirarucu", is an osteoglossiform fish that inhabits the Amazon River system, the western Orinoco and the river systems of the Guianas. This fish is one of the most important species for the development of intensive fish farming in the Amazonian region, being appreciated, highly demanded and regarded as a food fish of the highest quality (Queiroz and Crampton, 1999).
On A. gigas, only three species of branchiurans plus one unidentified Argulus sp. have been reported: Argulus chicomendesi Malta \& Varella, 2000, Dolops carvalhoi Lemos de Castro, 1949 and Dolops discoidalis (Bouvier, 1899) (Malta, 1984; Malta and Varella, 2000). The present study improves the knowledge on host and geographical range of Dolops striata (Bouvier, 1899).

Sixty A. gigas with $66.63 \pm 12.74$ of standard length were caught in a fish farm located in the municipality of Benavides, State of Pará, Brazil, during May 2017. Their gills, nasal fossae, fins and body surface were examined. Parasites found were collected manually from the fins and body surface using tweezers (Figure 1), fixed in ethanol $70 \%$ and mounted in lactic acid for observation. The classification of the species was based on Thatcher (2006) and in the original description of Dolops striata (Bouvier, 1899). Voucher specimens were deposited in the Crustacean Collection of the National Institute of Amazon Research, Manaus, AM, Brazil (INPA - 2303). The ecological terms in parasitology follow Bush et al. (1997)

Dolops striata (Figure 2) was found parasitizing A. gigas, with a prevalence of $100 \%$, and mean abundance of $10.03 \pm 2.55$. The main characteristics of this species are: Carapace elliptical, a little longer than wide, abdomen triangular, with well-rounded sides. The two spines on the ventral surface between the bases of these maxillipeds and a little posterior to them are very large, as wide as they are long, and have a broad, squarely cut tip. The swimming legs

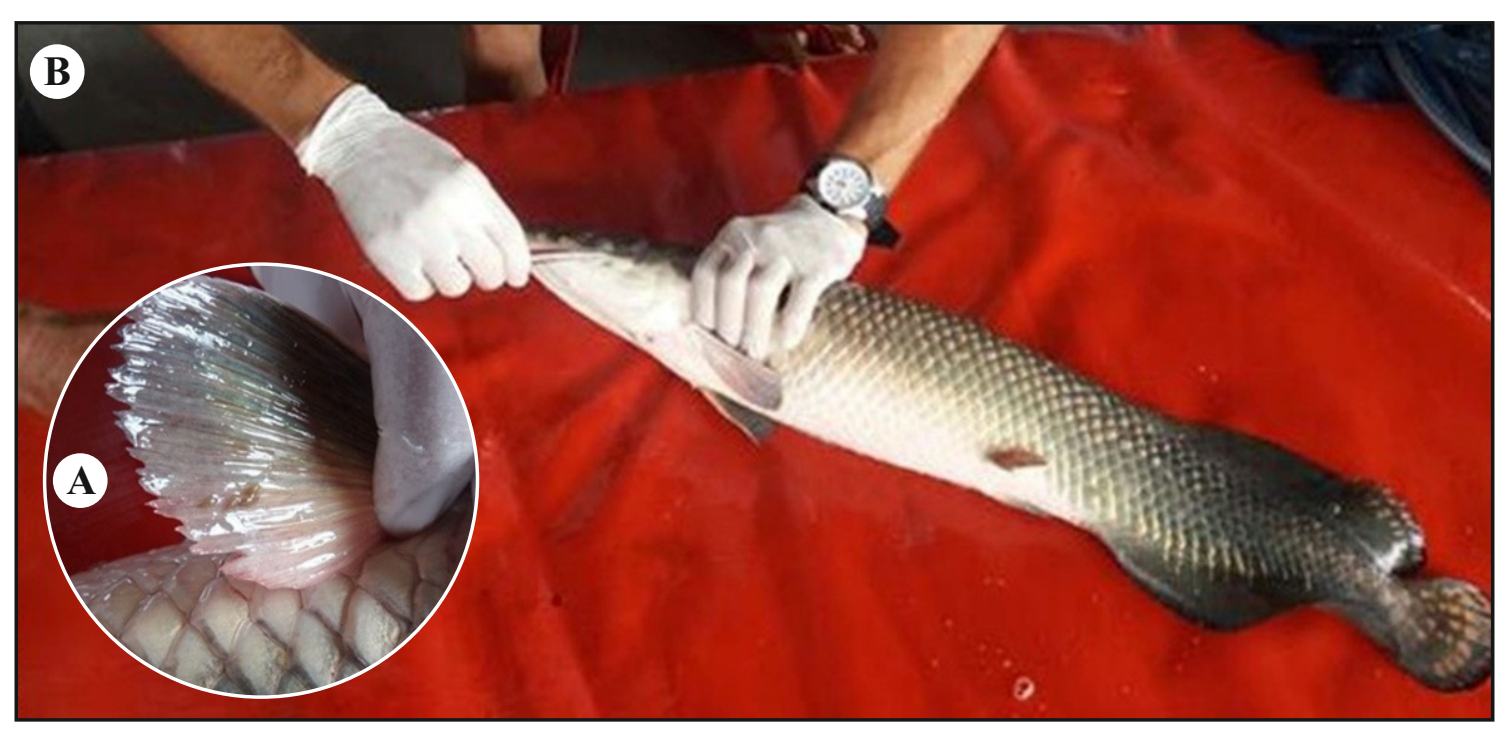

Figure 1. A. Fin of Arapaima gigas (Schinz, 1822) infested with Dolops striata (Bouvier, 1899). B. Collection and preservation of $D$. striata from the body surface of $A$. gigas 


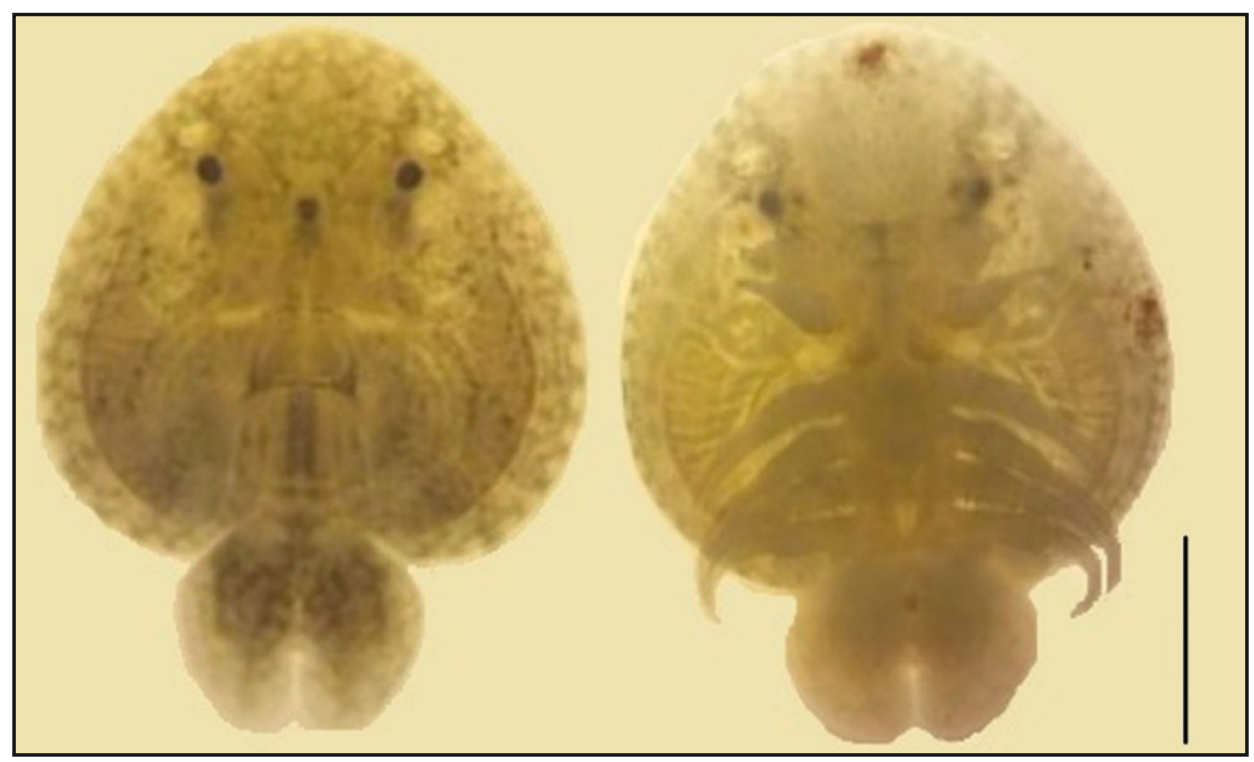

Figure 2. Dorsal and ventral view of Dolops striata (Bouvier, 1899 ) collected from Arapaima gigas (Schinz, 1822). Bar scale: $2 \mathrm{~mm}$

reach considerably beyond the edge of the carapace. The spines on the ventral surface are numerous in the region between the antennas, and are arranged in distinct transverse lines. Back of the antennae, in the lateral areas of the carapace, they are grouped in oblique lines, directed outward and backward. These spines wholly disappear opposite the anterior swimming legs, and there are none on the posterior portion of the ventral surface. The size of the collected specimens was $6 \pm 0.5 \mathrm{~mm}$.

Dolops Audouin, 1837 accommodates 11 species occurring in South-America and with two exceptions: D. ranarum (Stuhlmann, 1891) found in Africa and D. tasmanianus Fryer, 1969 that occurs only in Tasmania (Neethling and AvenantOldewage, 2016). The geographic distribution of $D$. striata in South-America is wide, occurring in the French Guiana (Bouvier 1899), in Venezuela (Weibezahn and Cobo, 1964), Paraguay (Cunnington 1931) and Argentina (Ringuelet, 1943). In Brazil it was reported in Rio Grande do Sul, Minas Gerais (Yamaguti 1963), and in the Solimões River, Amazonas (Malta and Varella, 1983; Malta, 1984). In the present study, the geographical distribution of this parasite in Brazil is expanded to the State of Pará.

Dolops striata was found on Leporinus fasciatus (Bloch, 1794), Leporinus sp., Schizodon fasciatus Spix \& Agassiz, 1829 (Characiformes, Anostomidae) (Malta and Varella, 1983; Malta,
1984), Hoplias malabaricus (Bloch, 1794) (Characiformes, Erythrinidae) and Synbranchus marmoratus Bloch, 1795 (Synbranchiformes, Synbranchidae,) (Luque et al., 2013). This parasite is not host-specific, being able to parasitize fish species from different taxonomic families and orders. This explains its presence in A. gigas, increasing the number of known hosts for this parasite species.

According to Malta and Varella (1983), D. striata is highly specific to the body surface of the parasitic fish, different to other Dolops species that can be found not only on the surface, but also in the gills and buccal cavity. In the present study, D. striata was found only on the body surface of $A$. gigas supporting the statement of the above-mentioned authors.

The intensity of infestation and prevalence of branchiurans in natural environments is generally low compared to fish pounds, where the infestation rates are higher (Ringuelet, 1943). This can be explained by Tavares-Dias et al. (2007) who mentioned that for ectoparasites is quite common higher parasite burdens among confined hosts. In this study, all sampled fish were parasitized by $D$. striata, supporting the idea that under controlled conditions, the chance of transmission of branchiurans is more efficient than under natural conditions. 
The effect that Dolops species have on their host is directly linked to their attachment, and secondarily to feeding (Avenant-Oldewage and Van As, 1990). The attachment by the maxillulae hooks causes haemorrhaging from the dermal layer of the skin and swelling from oedema. Secondary infection by bacteria and excessive mucous production can also be found (Avenant-Oldewage and Van As, 1990). The combination of these effects have implications for fish farmers in that a severe outbreak can occur in high density stocks and may decrease the ability of the fish against other immune challenges. In this study, the high prevalence detected warned the possibility of an increase in the number of $D$. striata infesting A. gigas, which may represent risk to the fish production in the region of the present study.

\section{ACKNOWLEDGEMENTS}

The authors thank the support of the "Laboratorio de Parasitologia de Peixes" (LPP) of the "Instituto Nacional de Pesquisas da Amazonia INPA"). GAMM received a doctoral scholarship from Conselho Nacional de Desenvolvimento Científico e Tecnológico (CNPq).

\section{REFERENCES}

Avenant-Oldewage,A.J.; Van As, G. 1990. The digestive system of the fish ectoparasite Dolops ranarum (Crustacea: Branchiura). Journal of Morphology, 204: 103-112.

Bouvier, M.E.L. 1899. Les crustacés parasites du I genre Dolops (Audouin). Bulletin de la Societé Philomathique. Paris Serie, 10: 53-81.

Bush, A.O.; Lafferty, K.D.; Lotz, J.M. and Shostak, A.W. 1997. Parasitology meets ecology on its own terms: Margolis et al. revisited. The Journal of parasitology, 575-583.

Cunnington, W.A. 1931 - Reports of expedition to Brasil and Paraguai in 1926-27. Journal of the Linnean Society, 37: 259-264.

Luque, J.L.; Vieira, F.M., Takemoto, R.M.; Pavanelli, G.C.; Eiras, J.C. 2013. Checklist of Crustacea parasitizing fishes from Brazil. Check List, 9: 1449-1470.
Malta, J.C.O. 1984. Os peixes de um lago de várzea da Amazônia Central (Lago Janauacá, Rio Solimões) e suas relações com os crustáceos ectoparasitas (Branchiura: Argulidae). Acta Amazonica, 14:355-372.

Malta, J.C.O.; Varella, A. 1983. O Argulídeos (Crustacea: Branchiura) da amazônia brasileira 3. Aspectos da ecologia de Dolops striata Bouvier, 1899 e Dolops carvalhoi Castro, 1949. Acta Amazonica, 13: 299-306.

Malta, J.C.O.; Varella, A. M. B. 2000. Argulus chicomendesi sp. n.(Crustacea: Argulidae) parasita de peixes da Amazônia brasileira. Acta Amazonica, 30: 481-489.

Neethling, Lourelle A.M.; Avenant-Oldewage, A. 2016. "Branchiura - a compendium of the geographical distribution and a summary of their biology." Crustaceana, 89: 1243-1446.

Queiroz, H.L. and Crampton, W. 1999. A preservação e o uso sustentado dos pirarucus (Arapaima gigas, Osteoglossidae) em Mamirauá. Estratégias para manejo de recursos pesqueiros em Mamirauá. Brasília. Sociedade Civil Mamirauá, Tefé, Brasil, 197p.

Ringuelet, R. 1943. Revision de los argulideos argentinos (Crustacea, Branchiura). Revista del Museo de La Plata, 3: 42 - 125.

Tavares-Dias, M.; De Moraes, F.R.; Onaka, E.M. and Rezende, P.C.B. 2007. Changes in blood parameters of hybrid tambacu fsh parasitized by Dolops carvalhoi (Crustacea, Branchiura), a fish louse. Veterinarski Arhive, 77: 355-363.

Thatcher, V.E. 2006. Amazon Fish Parasites. Moscow: Pensoft Publishers, Sofia. 508p.

Weibezahn, F.H. and Cobo, T. 1964. Seis argulidos (Crustacea, Branchiura) parásitos de peces dulceacuícolas en Venezuela, con descripción de una nueva especie del genero Argulus. Acta Biologica Venezuelica., 4: 119-144.

Yamaguti, S. 1963. Parasitic Copepoda and Branchiura of fishes. Interscience Publishers, New York, 1104p.

Recibido: 05 de Setiembre del 2017

Aceptado para publicación: 06 de Octubre del 2017 